\title{
Assessing the effects of disaggregated public spending on green economic growth: The case of China
}

Thierry Y. Gnangoin ( $\nabla$ thierrybienvenu2010@yahoo.fr)

Dongbei University of Finance and Economics https://orcid.org/0000-0001-8132-635X

Liangsheng Du

Dongbei University of Finance and Economics

Akadje Jean Roland Edjoukou

Dongbei University of Finance and Economics

Djeri Sow

Dongbei University of Finance and Economics

Nyande Fania

Dongbei University of Finance and Economics

\section{Research Article}

Keywords: Public spending, Green economic growth index, Principal component analysis, FMOLS, DOLS, China

Posted Date: March 30th, 2021

DOI: https://doi.org/10.21203/rs.3.rs-283770/v1

License: (1) This work is licensed under a Creative Commons Attribution 4.0 International License. Read Full License 


\author{
Thierry Y. Gnangoin ${ }^{1}$ \\ School of Economics \\ Tel: 008613019498971 \\ thierrybienvenu2010@yahoo.fr \\ No.217, Jianshan Street, Shahekou District, Dalian, China \\ Dongbei University of Finance and Economics, Dalian (116025), China \\ Felix Houphouet-Boigny University of Abidjan, Cote d'Ivoire \\ Liangsheng Du \\ School of Economics \\ No.217, Jianshan Street, Shahekou District, Dalian, China \\ Dongbei University of Finance and Economics, Dalian (116025), China \\ Akadje Jean Roland Edjoukou \\ School of Accounting \\ No.217, Jianshan Street, Shahekou District, Dalian, China \\ Dongbei University of Finance and Economics, Dalian (116025), China \\ Djeri Sow \\ School of Economics \\ No.217, Jianshan Street, Shahekou District, Dalian, China \\ Dongbei University of Finance and Economics, Dalian (116025), China
}

${ }^{1}$ Corresponding author 


\section{Nyande Fania}

\section{School of Accounting}

No.217, Jianshan Street, Shahekou District, Dalian, China

Dongbei University of Finance and Economics, Dalian (116025), China 


\section{Declarations}

\section{Ethics approval and consent to participate}

Not applicable

\section{Consent for publication}

Not applicable

\section{Availability of data and material}

The datasets generated and/or analyzed during the current study are from the 2019 World Development Indicators, and the 2019 International Monetary Fund Government Finance Statistics.

\section{Competing interests}

The authors declare that they have no competing interests

\section{Funding}

This research receives no external funding

\section{Authors' contributions}

Conceptualization: TYG; Methodology: TYG; Formal analysis and investigation: AJRE; Writing - original draft preparation: TYG; Writing - review and editing: NF; Project administration: LD; Software: SD; Supervision: LD.

Acknowledgments

Not applicable 


\begin{abstract}
$\underline{\text { Abstract }}$
This article examines the linear and nonlinear relationship between disaggregated public spending and green economic growth in China's case for 1993Q1-2018Q4. We used the principal component analysis approach to calculate the index of green economic growth and analyzed quarterly data through DOLS and FMOLS models. We found that public spending on economic affairs, public spending on health, inflation rate, and trade openness have a positive effect on green economic growth, while public spending on housing has a negative effect on green economic growth. Besides, the results showed a linear relationship between public spending on economic affairs and green growth; while a nonlinear relationship between public spending on housing and green economic growth, and between public spending on health and green economic growth. Lastly, the results showed that the 2015Q1 breakpoint has a negative and significant effect on green growth, while the 2008 financial crisis effect is not significant.
\end{abstract}

Keywords: Public spending, Green economic growth index, Principal component analysis, FMOLS, DOLS, China

JEL code: H5, O47, Q57, Q58 


\section{Introduction}

The worsening of climate change leads governments to implement policies that pay attention to environmental protection. This assessment is clearly demonstrated by the Chinese President Xi's speech during the $12^{\text {th }}$ BRICS summit in November 2020. In effect, during this summit, he stated for the building of a community with a shared future for mankind, through mainly, the fight against Covid-19, poverty elimination, and environment protection. So, these policies have to combine economic growth and environmental protection. This type of economic growth, socalled "green economic growth" considers the combination of economic growth, resources conservation, and environmental friendliness (Matraeva et al., 2019). This growth is in line with nine sustainable development goals (Good health and well-being; clean water and sanitation; affordable and clean energy; industry innovation and infrastructure; sustainable cities and communities; responsible consumption and production; climate action; life below water; life on land). Besides, according to the United Nations Economic and Social Commission for Asia and the Pacific (UNESCAP, 2012) and Korea International Cooperation Agency (KOICA, 2012), the concept of green growth is a practical way of reconciling economic growth and environmental sustainability. So, green growth carries with it the claim that environmental protection is compatible with economic growth.

Considering the importance of the environmental issue, authors examined the determinants of this growth and its effects on the economy, using many study cases (OCDE; Korea; Kenya; China...). Meanwhile, these authors did not consider the nonlinear impact of disaggregated public spending on green economic growth.

So, in this study, we attempt to fill this gap and also contribute to the analysis of Lin and Zhu (2019), firstly by constructing an index of green growth through the principal component analysis method in the case of China. Secondly, by analyzing the linear and nonlinear relationship between disaggregated public spending and green growth. Then, by paying attention to the effect of the 2015Q1 breakpoint and the 2008 financial crisis, while considering this relationship.

As public spending affects economic growth, we assume that this spending directly or indirectly affects this country's environment. Hence, it is important to find fiscal mechanisms that contribute to growth while reducing pollution. This relationship's nature will be detailed in this analysis, paying attention to the kind of public spending which are green growth contributors or not. This work will be presented as follows: firstly, we will present the study background, then the literature review, following by the methodology of analysis, then the study results, discussion, conclusion, and policy implications.

\section{Literature review}

The importance of public spending on growth management has been highlighted by the Keynesian School. According to this school of thought, government action through public spending and taxes influence economic growth. Contributing to the analysis of this relationship, authors such as Wang et Shao (2019) showed that selected spending such as research and development spending positively influence green economic growth; green economic growth, which is considered by Reilly (2012), and Musango et al. (2014), as an efficient way for mitigating 
environmental degradation, saving resources, and fostering economic growth. Shah et al. (2015) stated that fiscal instruments influence the transition towards green economy in Asian countries. Bagheri et al. (2018) also considered this issue in the case of Canada.

Other authors such as Yi and Liu (2015), Li and Xu (2018), Qin and al. (2019), and Wu and al. (2019) examined the effects of other variables on green economic growth. Yi and Liu (2015) analyzed the growth situation of the green economy of China by considering variables like population changes and education level... Li and $\mathrm{Xu}$ (2018) confirmed that the abundance of resources in one region positively influences environmental degradation. Qin et al. (2019) and $\mathrm{Wu}$ and al. (2019), respectively, paid attention to the role of iron and steel industries and the electricity substitution policy effect while considering the determinants of green economic growth in China's case.

\section{Construction of green growth index (GGI)}

In this study, we construct the green growth index (GGI) in China's case through the principal component analysis methodology. The principal component analysis (PCA) is a factor analysis technique that reduces extensive data set or a series of initial correlated variables into a minimum of components (small data set or new variables) encompassing most of the original variables' information. So, it consists of discovering the patterns amongst the variables and empowers the redacting of variables into a new composite index that consolidates from these interrelated variables. We apply the PCA method on five variables (GDP/k; GFCF; Labor; CO2/k; Energy) to construct the green growth index in China's case.

As Lin and Zhu (2019), we consider:

- The gross domestic product per capita (GDP/k);

- The gross fixed capital formation (GFCF) in the percentage of GDP, which shows how much of the new value-added in the economy is invested rather than consumed;

- The labor force (Labor), which is the percentage of labor force per capita;

- The $\mathrm{CO} 2$ emissions per capita (CO2/k), which is $\mathrm{CO} 2$ emissions in metric tons per capita;

- The energy consumption per capita (Energy), which is the $\mathrm{kg}$ of oil equivalent per capita.

The variables GDP/k, Labor, Energy take account of the change in development while the variables CO2/k and Energy consider the change in environment.

Similar studies like Keho (2012); the composite index is calculated through the PCA method as follows:

$G G I=\sum_{k=1}^{n} \phi_{k} \times G G_{k}$

Where $G G I=(G D P / k ; G F C F ;$ labor $; C O 2 / k ;$ Energy $)$ is the composite index of green growth. 
$\phi_{k}$ is the coefficient of explained variance of each element $(k)$ in GDP/k; GFCF; Labor; CO2/k; and Energy. $G G_{k}$ denotes the factor score of each green growth variable.

\section{Methodology}

\subsection{Database}

This study examines China's quarterly data for the period 1993Q1-2018Q4. These data, presented in table 1, are from the the International Monetary Fund Government Finance Statistics (IMF, 2019), and the World Development Indicators (World Bank, 2019) and have been used according to their availability. These data can be described as following:

- Green growth index, which is the index of green growth for China (GGI);

- Lagged green growth index, which is the index of green growth for China during period $t-1$;

- Public spending on environmental protection (Env), which includes spending for: waste management, pollution abatement, protection of biodiversity and landscape, research and development environment protection, and environmental protection not elsewhere classified (n.e.c). It is measured in percentage of total government expenditure (TGE);

- Public spending on general public services (General), which includes spending for: executive and legislative organs, financial and fiscal affairs, general services, basic research, external affairs, research, and development general public services, general public services not elsewhere classified (n.e.c). It also includes foreign economic aid, public debt transactions, and transfers of a general character between different levels of government. It is measured in percentage of total government expenditure (TGE);

- Public spending on defense (Defense), which includes spending for: military defense, civil defense, foreign military aid, research and development defense and defense not elsewhere classified (n.e.c). It is measured in percentage of total government expenditure (TGE);

- Public spending on public order and safety (Order), which includes spending for: police services, fire protection services, law courts, prisons, research and development public order and safety, and public order and safety not elsewhere classified (n.e.c). It is measured in percentage of total government expenditure (TGE);

- Public spending on economic affairs (Affairs), which includes spending for : general economic , commercial and labor affairs, agriculture, forestry, fishing and hunting, fuel and energy, mining, manufacturing and construction, transport, communication, others industries, research and development economic affairs and economic affairs not elsewhere classified (n.e.c). It is measured in percentage of total government expenditure (TGE);

- Public spending on housing and community amenities (Housing), which includes public spending for: housing development, community development, water supply, street lighting, research and development 
housing and community amenities, housing and community amenities not elsewhere classified (n.e.c). It is measured in percentage of total government expenditure (TGE);

- Public spending on health (Health), which includes public spending for: medical products, appliances and equipment, outpatient services, hospital services, public health services, research and development health, and health not elsewhere classified. It is measured in percentage of total government expenditure (TGE);

- Public spending on recreation (Recreation), culture and religion, which includes public spending for: recreational and sporting services, cultural services, broadcasting and publishing services, religious and other community services, research and development recreation, culture and religion, recreation, and culture and religion not elsewhere classified (n.e.c). It is measured in percentage of total government expenditure (TGE);

- Public spending on education (Education), which includes public spending for: pre-primary and primary education, secondary education, post-secondary non-tertiary education, tertiary education, education not defined by level, subsidiary services to education, research and development education, and education not elsewhere classified (n.e.c). It is measured in percentage of total government expenditure (TGE);

- Public spending on social protection (Social), which includes public spending for: sickness and disability, old age, survivors, family and children, unemployment, housing, social exclusion not elsewhere classified, research and development social protection, and social protection not elsewhere classified (n.e.c). It is measured in percentage of total government expenditure (TGE);

- Inflation (i.e., GDP deflator) which is an increases in the general level of prices of goods and services. It is measured in percentage;

- Trade, which is the sum of China exports and imports as a share of its gross domestic product. It is measured in percentage;

- Crisis which reflects the effects of the 2008 financial crisis during the studied period. It is a dummy variable. 
Table 1: Variables description

\begin{tabular}{|lcc|}
\hline Variables & Description & Unit \\
\hline GGI & Green growth index per capita & index \\
DGGI & Lagged green growth per capita & index \\
General & Public spending on general public services & percentage of TGE \\
Defense & Public spending on defense & percentage of TGE \\
Order & Public spending on public order and safety & percentage of TGE \\
Affairs & Public spending on economic affairs & percentage of TGE \\
Env & Public spending on environmental protection & percentage of TGE \\
Housing & Public spending on housing and community amenities & percentage of TGE \\
Health & Public spending on health & percentage of TGE \\
Recreation & Public spending on recreation, culture and religion & percentage of TGE \\
Edu & Public spending on education & percentage of TGE \\
Social & Public spending on social protection & percentage of TGE \\
Trade & Trade openness & percentage of GDP \\
Inf & inflation rate & percentage \\
Crisis & 2008 financial crisis & dummy \\
\hline
\end{tabular}

The descriptive statistics (Table 2) of these variables shows that the minimum value of the studied variables is negative except for TRADQ (2.590). The normality of data was analyzed through the Jacque-Bera test. Its results depicts that the green growth index (0.389) follows a normal distribution. 
Table 2: Descriptive table (103 observations)

\begin{tabular}{|l|l|l|l|l|l|l|l|l|l|l|l|l|l|l|l|}
\hline & GGIQ & DEFQ & EDUQ & GENQ & ENVQ & AFFQ & INFQ & HEALQ & HOUQ & ORDQ & RECQ & SOCQ & TRADQ & CRISQ \\
\hline Mean & 0.005 & 0.659 & 1.748 & 1.623 & 0.310 & 4.455 & 4.600 & 0.689 & 0.984 & 0.677 & 0.215 & 2.957 & 4.865 & 0.039 \\
Median & -0.281 & 1.000 & 1.971 & 2.324 & 0.298 & 5.428 & 3.082 & 0.611 & 0.082 & 0.972 & 0.262 & 1.774 & 4.944 & 0.000 \\
Max. & 2.070 & 1.538 & 4.326 & 7.065 & 0.921 & 14.909 & 21.082 & 3.445 & 3.904 & 1.757 & 0.507 & 8.314 & 6.244 & 1.063 \\
Min. & -2.159 & -0.757 & -2.200 & -1.784 & -0.450 & -4.058 & -1.706 & -1.765 & -1.666 & -0.918 & -0.250 & -4.313 & 2.590 & -0.156 \\
St. Dev. & 0.998 & 0.668 & 1.816 & 1.823 & 0.330 & 4.672 & 5.266 & 0.962 & 1.217 & 0.692 & 0.221 & 3.231 & 1.020 & 0.199 \\
Jarque- & 1.887 & 14.262 & 12.520 & 7.683 & 8.955 & 8.245 & 59.708 & 32.739 & 8.112 & 12.921 & 13.234 & 10.050 & 8.528 & 1947.042 \\
Bera & & & & & & & & & & & & \\
Prob. & 0.389 & 0.001 & 0.002 & 0.021 & 0.011 & 0.016 & 0.000 & 0.000 & 0.017 & 0.002 & 0.001 & 0.007 & 0.014 & 0.000 \\
\hline
\end{tabular}

Table 3 shows the correlation relationship between the studied variables. This table indicates that the link between GGIQ and HEALTHQ is negative, while those between GGIQ and the others variables is positive, suggesting that public spending on health may negatively influence green economic growth in China.

Besides, the table 3 shows that the link between GGIQ and INFQ, and GGIQ and CRISQ, is not significant, suggesting that the link between these variables may not be effective. 
Table 3: Correlation table

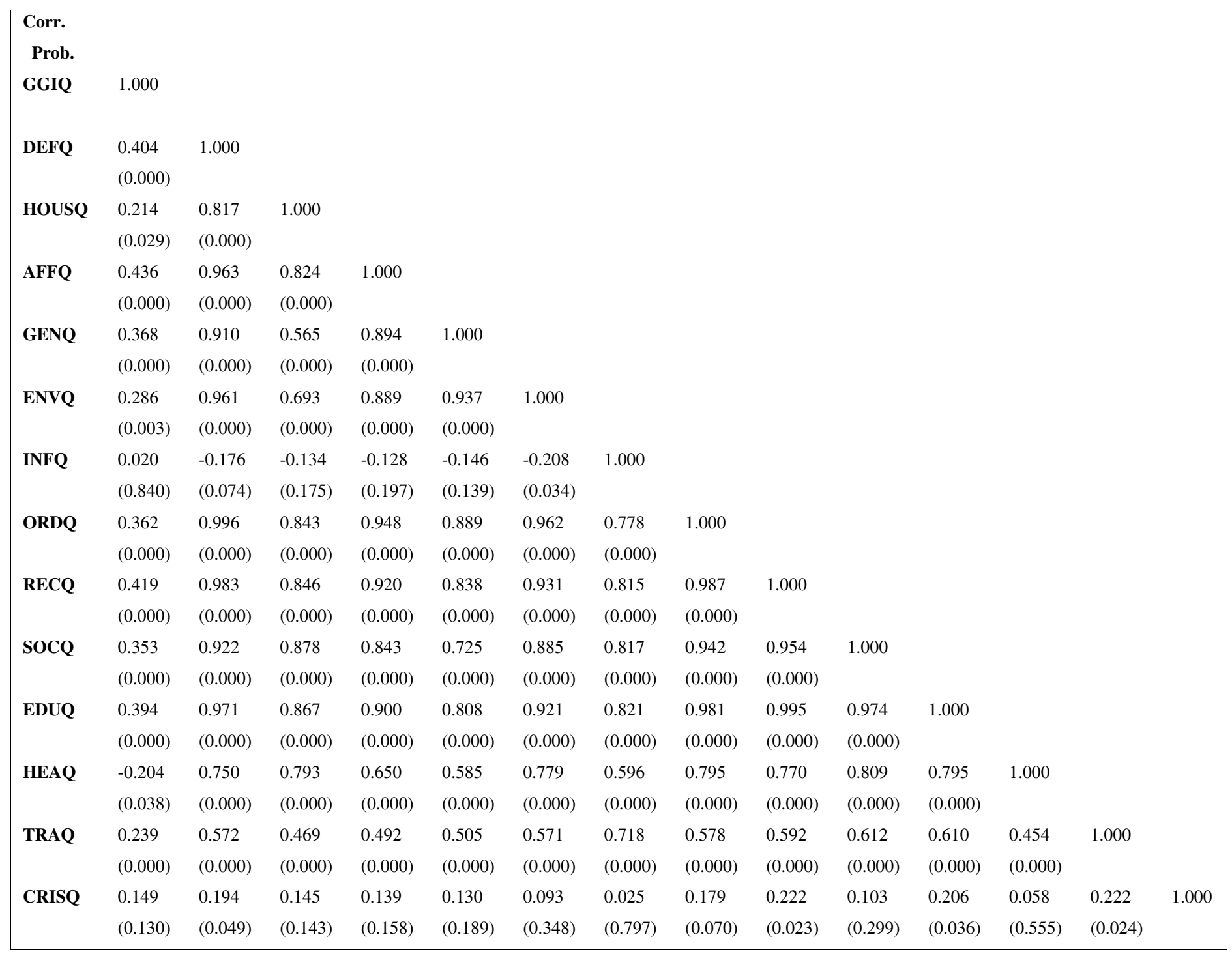

\section{Empirical analysis.}

\subsection{Model specification}

To study the relationship between public spending and green growth, we estimate the following model:

$$
G G I_{t}=\alpha+\beta G G I_{t-1}+\gamma X_{t}^{1}+\phi X_{t}^{2}+\varepsilon_{t}
$$

Where, 
$\alpha$, is the intercept, $\beta, \gamma, \phi$, the coefficients to be estimated, $t$ characterizes the time period, and $G G I_{t}$, the index of green growth.

$X_{t}^{1}=\left[e d u q_{t}\right.$, defq $_{t}$, housq $_{t}$, aff $_{t}$, genq $_{t}, e n v q_{t}$, ord $_{t}$, recreaq $_{t}$, socialq $_{t}$, health $\left._{t}\right]$ is a set of public spending as a share of total government expenditure (TGE),

$X_{t}^{2}=[\inf q$, tradq, crisisq $]$ is a set of controls variables, and $\varepsilon_{t}$, the error term.

We estimate the equation (2) by using 2 approaches: the dynamic ordinary least squares (DOLS), and the feasible modified least squares (FMOLS). Before estimating this equation, we check the variables level of stationarity and the long-run cointegration among variables.

\subsection{Unit root tests}

We investigate the stationnarity properties of our study variables by using conventional tests: the Dickey-Fuller generalized least squares (DF-GLS) test suggested by Elliott, Rothenberg and Stock in 1996, and the Phillips-Perron (PP, 1988) test.

Besides, we check the existence of breakpoint in our data through the Zivot-Andrews (1992) breakpoint test. The Zivot-Andrews (1992) breakpoint stationnarity test is used in order to avoid misspecification and account for structural breaks in studied variables. We use this test mainly because of the importance of structural changes in the behavior of fiscal variables. This test allows for one structural break and identifies the date of the break, hence facilitating the analysis of whether the break is associated with any specific event (Feridun, 2009).

An important advantage of this test is that no prior knowledge of the structured break date is required, and it prevents the problem of data mining (Glynn, Perera, Verma, 2007). The procedure selects the break-date which minimizes the one-sided t-statistic from among all possible breakpoints. In the Zivot-Andrews test, the null hypothesis is that the variable under investigation contains a unit root with a drift that excludes any structural break. The alternative hypothesis is that the series is a trend-stationary process in which a one-time break in the trend variable occurs at an unknown point in time.

The three different strands of the test are shown in equations (3), (4), (5), which suggest a break in the intercept, trend, intercept and trend, respectively.

$$
\begin{gathered}
\Delta z_{t}=v_{1}+v_{2} t+\xi z_{t-1}+\psi D U_{t}+\sum_{i=0}^{r} \omega_{i} \Delta z_{t-i}+\varepsilon_{t} \\
\Delta z_{t}=v_{1}+v_{2} t+\xi z_{t-1}+\delta D T_{t}+\sum_{i=0}^{r} \omega_{i} \Delta z_{t-i}+\varepsilon_{t}
\end{gathered}
$$


$\Delta z_{t}=v_{1}+v_{2} t+\xi z_{t-1}+\psi D U_{t}+\varphi D T_{t}+\sum_{i=0}^{r} \omega_{i} \Delta z_{t-i}+\varepsilon_{t}$

Where,

$T_{b}$ is the possible breakpoint, $r$ is the upper limit of the lag length of the explanatory variables,

$D U_{t}$ is a sustained dummy variable that captures a shift in the intercept, and $D T_{t}$ represents a shift in the trend occurring at time $T_{b}$.

We define $D U_{t}$ and $D T_{t}$ as follows: $D U_{t}=1$ if $t \mathrm{f} T_{b}, D U_{t}=0$, otherwise; $D T_{t}=1$, if $t \mathrm{f} T_{b}, D T_{t}=0$, otherwise.

The results of all tests are presented in Table 4 and Table 5. These results (Table 4) indicate that public spending on education is not stationary (EDUQ), while the variables green growth index (GGIQ), public spending on defense (DEFQ), public spending on housing (HOUSQ), public spending on economic affairs (AFFQ), public spending on general public services (GENQ), public spending on environmental protection (ENVQ), public spending on order and safety (ORDQ), public spending on recreation (RECREAQ), public spending on Social protection (SOCQ), public spending on health (HEALQ), Trade openness (TRADQ), and financial crisis (CRISISQ) are stationary in first difference I(1). Concerning the Zivot-Andrews breakpoint, the results (Table 5) showed that the breakpoint among variables is $2015 \mathrm{Q} 1$. 
Table 4: Conventional unit roots tests

\begin{tabular}{|c|c|c|c|c|}
\hline \multirow[t]{2}{*}{ Variables } & \multicolumn{2}{|c|}{ DF-GLS } & \multicolumn{2}{|c|}{ Phillips-Perron } \\
\hline & Level & $\mathrm{I}(1)$ & Level & $\mathrm{I}(1)$ \\
\hline GGIQ & -1.557 & $-1.928^{*}$ & -1.330 & $-5.042 * * *$ \\
\hline $\begin{array}{l}\text { EDUQ } \\
\end{array}$ & -1.607 & -0.461 & -1.126 & -1.318 \\
\hline DEFQ & -1.533 & $-2.267 * *$ & -1.257 & $-2.664 *$ \\
\hline HOUSQ & -1.440 & $-1.747 *$ & -1.355 & $-4.139 * *$ \\
\hline AFFQ & -1.320 & $-1.649 *$ & -0.984 & $-4.691 * * *$ \\
\hline GENQ & -1.473 & $-2.011 * *$ & -1.767 & $-4.309 * * *$ \\
\hline ENVQ & -1.592 & $-2.543 * *$ & -1.723 & $-3.452 * *$ \\
\hline ORDQ & -1.667 & $-1.949 *$ & -1.315 & $-2.855^{*}$ \\
\hline RECREAQ & -1.632 & $-2.445 * *$ & -1.120 & $-2.302^{*}$ \\
\hline SOCIALQ & -0.196 & $-2.268 * *$ & -1.216 & $-3.941 * *$ \\
\hline INFQ & -1.502 & $-2.536^{* *}$ & -2.170 & $-4.969 * * *$ \\
\hline $\begin{array}{l}\text { TRADEQ } \\
\end{array}$ & 0.823 & $-2.438 * *$ & -1.947 & $-5.430 * * *$ \\
\hline CRISISQ & -0.765 & $-3.377 * * *$ & -2.554 & $-10.672 * * *$ \\
\hline HEALTHQ & -0.767 & $-2.768 * * *$ & -1.976 & $-4.315^{* *}$ \\
\hline
\end{tabular}

$*, * *, * * *$ denote the statistical significance at $10 \%, 5 \%, 1 \%$ level 
Table 5: Zivot-Andrews unit roots tests

\begin{tabular}{|c|c|c|c|c|c|c|}
\hline \multirow[t]{2}{*}{ Variables } & \multicolumn{2}{|c|}{ Zivot-Andrews } & \multicolumn{2}{|c|}{ Zivot-Andrews } & \multicolumn{2}{|l|}{ Zivot-Andrews } \\
\hline & Intercept & Break point & Trend & Break point & $\begin{array}{l}\text { Intercept and } \\
\text { trend }\end{array}$ & Break point \\
\hline GGIQ & $-9.134 * * *$ & $2014 Q 4$ & $-3.476^{* * *}$ & 2012Q4 & $-5.887 * * *$ & 2015Q1 \\
\hline EDUQ & -0.687 & 2006Q2 & $-0.611^{* * *}$ & 2015Q1 & $-0.694 * *$ & 2015Q1 \\
\hline DEFQ & $-1.493^{* * *}$ & 2004Q2 & $-1.113^{* * *}$ & 2015Q1 & $-1.493 * * *$ & 2004Q2 \\
\hline HOUSQ & $-2.398 * * *$ & 2006Q2 & $-0.689 * * *$ & 2015Q1 & $-1.536^{* * *}$ & 2006Q2 \\
\hline AFFQ & $-2.160 * * *$ & 2004Q3 & $-1.001 * * *$ & 2015Q1 & $-2.320 * * *$ & 2004Q4 \\
\hline GENQ & $-4.490 * * *$ & 2004Q2 & $-1.910 * *$ & 2015Q1 & $-4.490 * * *$ & 2004Q2 \\
\hline ENVQ & $-2.725^{* * *}$ & 2004Q2 & $-1.873^{* * *}$ & 2015Q1 & $-2.725^{* * *}$ & 2006Q2 \\
\hline ORDQ & $-3.221 * * *$ & 2006Q2 & $-0.981 * * *$ & 2015Q1 & $-2.857 * * *$ & 2006Q2 \\
\hline RECREAQ & -0.679 & 2006Q2 & $-0.875^{* * * *}$ & 2015Q1 & $-0.898^{*}$ & 2015Q1 \\
\hline SOCIALQ & $-1.933 * *$ & 2007Q2 & $-0.882 * * *$ & 2015Q1 & $-1.401 * *$ & 2015Q1 \\
\hline INFQ & $-3.378 * * *$ & 2003Q3 & $-1.433 * *$ & 2007Q2 & -3.409 & 1999Q2 \\
\hline TRADEQ & -2.695 & 2008Q2 & -2.560 & 1999Q3 & $-4.164 * *$ & 2005Q1 \\
\hline CRISISQ & $-3.800 * * *$ & 2010Q1 & -2.813 & 2008Q2 & $-4.012 * * *$ & 2007Q2 \\
\hline HEALTHQ & -2.256 & 2006Q2 & $-1.973^{* *}$ & $2007 \mathrm{Q} 2$ & -2.256 & 2006Q2 \\
\hline
\end{tabular}

\subsection{Cointegration test}

Following the stationarity test, we employ the autoregressive distributive lag (ARDL) bound test, developed by Pesaran, Shin, and Smith (2001) to check the long-run cointegration between the studied variables. We employ this test because it gives rigorous results for a small sample and allows multiple predictors to have different lag orders (Sarkodie and Adams, 2018). It also enabling modeling without the need to resort to stationarity analysis and providing superior results in samples with limited size (Narayan and Narayan, 2004 and Ertugrul et al., 2018). The null hypothesis for the Wald test assumes no cointegration among parameters while the alternative hypothesis assumes cointegration among variables. When the null hypothesis of no cointegration is rejected (cointegration among variables), it also means that the calculated F-statistic is greater than the upper bound critical value. If the computed F-statistics is less than the lower bound critical value, then we cannot reject the null hypothesis of no cointegration. 


\section{Table 6: Bound cointegration test}

\begin{tabular}{|l|l|l|l|l|}
\hline & & F-statistic & & Conclusion \\
\hline Critical values & $3.675^{* *}$ & & Cointegration \\
\hline Significance level & & $\mathrm{I}(0)$ & $\mathrm{I}(1)$ & \\
\hline $1 \%$ & 5.3 & 3.17 & \\
$5 \%$ & 3.83 & 3.22 & \\
$10 \%$ & 3.19 & 2.72 & \\
\hline
\end{tabular}

$*, * *, * * *$ denote the statistical significance at $10 \%, 5 \%, 1 \%$ level

The result of cointegration test in Table 6 shows the existence of the long-run cointegration among variables at 5\% level of significance.

\subsection{DOLS and FMOLS estimations}

After determining the cointegration among variables, the long-run relationship among them is examined through the dynamic ordinary least squares (DOLS) and the fully modified least squares (FMOLS). The DOLS method was put forward by Stock and Watson (1993), and extended by Kao and Chiang (1999, 2001). This method takes account of the endogeneity and autocorrelation issues by increasing the lags, leads, and contemporaneous values in the regression. It also yields better results and high efficiency in case of small samples (Danish, Zhang, Hassan and Iqbal, 2019; Dogan and Seker, 2016). We confirm the results of DOLS method using the FMOLS approach developed by Phillips and Hansen (1990). This method also addresses serial correlation problem and, endogeneity of the regressors by incorporating the Philips and Hansen (1990) semi-parametric correction into the OLS estimator. 
Table 7: DOLS results

\section{Dependent variable: GGIQ}

\begin{tabular}{|c|c|c|}
\hline Variables & Coefficient & Prob. \\
\hline LAG1 & 1.418 & $0.000 * * *$ \\
\hline DEFENSEQ & 0.225 & 0.843 \\
\hline HOUSINGQ & -0.366 & $0.027 * *$ \\
\hline AFFAIRSQ & 0.109 & $0.027 * *$ \\
\hline GENERALQ & 0.029 & 0.702 \\
\hline ENVIRONQ & -1.291 & 0.259 \\
\hline INFQ & 0.009 & $0.000 * * *$ \\
\hline ORDERQ & -0.333 & 0.882 \\
\hline RECREAQ & -1.523 & 0.344 \\
\hline SOCIALQ & -0.006 & 0.912 \\
\hline HEALTHQ & 0.742 & $0.001 * * *$ \\
\hline TRADEQ & 0.040 & $0.000 * * *$ \\
\hline CRISISQ & -0.034 & 0.847 \\
\hline BREAKQ & -4.401 & $0.000 * * *$ \\
\hline R-squared & 0.999 & \\
\hline Adjusted R-squared & 0.999 & \\
\hline
\end{tabular}

$*, * *, * * *$ denote the statistical significance at $10 \%, 5 \%, 1 \%$ level

The DOLS analysis results (Table 7) shows a positive effect of previous green economic growth, public spending on economic affairs, and public spending on health on green economic growth. The results also show a positive effect of inflation and trade openness on green economic growth. However, there is a negative relationship between public spending on housing, the 2015 breakpoint and, green economic growth. 
Table 8: Robustness results (FMOLS)

\section{Dependent variable: GGIQ}

\begin{tabular}{|c|c|c|}
\hline Variables & Coefficient & Prob. \\
\hline LAG1 & 1.125 & $0.000 * * *$ \\
\hline DEFENSEQ & -0.336 & 0.336 \\
\hline HOUSINGQ & -0.120 & $0.044 * *$ \\
\hline AFFAIRSQ & 0.034 & $0.021^{* *}$ \\
\hline GENERALQ & 0.057 & 0.601 \\
\hline ENVIRONQ & -0.190 & 0.615 \\
\hline INFQ & 0.005 & $0.000 * * *$ \\
\hline ORDERQ & 0.606 & 0.127 \\
\hline RECREAQ & -0.184 & 0.768 \\
\hline SOCIALQ & -0.054 & 0.183 \\
\hline HEALTHQ & 0.146 & $0.035^{* *}$ \\
\hline TRADEQ & 0.021 & $0.000 * * *$ \\
\hline CRISISQ & -0.131 & 0.205 \\
\hline BREAKQ & -3.566 & $0.000 * * *$ \\
\hline R-squared & 0.999 & \\
\hline Adjusted R-squared & 0.999 & \\
\hline
\end{tabular}

Using the FMOLS (Table 8) approach to also estimate the equation (2), we found a positive relationship between previous green economic growth, public spending on economic affairs, public spending on health, inflation, trade openness, and green economic growth. While, there is a negative relationship between public spending on housing, the 2015 breakpoint and green economic growth. Hence, we can conclude that the DOLS approach results are robust.

\subsection{Nonlinear approach: The concept of the Armey curve}

Armey (1995) stated that public expenditure increases economic growth until a certain level from which, public expenditure reduces growth. Armey (1995) puts this phenomenon into a graphic using Kuznets (1955) and Laffer (1980s) model to explain the relationship between government spending and economic growth. In doing so, he indicates that government spending and economic growth can be modeled as a quadratic function (inverted Ushaped curve), which assumes a role for both the linear term and the squared of government expenditure in the economic growth process. The approach used in this study, follows the Armey analysis relating public spending to 
green growth. We add in the econometrical model the square of the considered government spending. The inclusion of this variable contributes to empirically verify the phenomenon of Armey curve within this framework.

$$
G G I_{t}-G G I_{t-1}=\alpha_{0}+\gamma_{1} g_{t}-\gamma_{2} g_{t}^{2}+\phi X_{t}^{2}+\varepsilon_{t}
$$

The positive coefficient of the linear $g$ term is related to the effect of public spending on output, and the expecting negative effects of the government spending increasing. This equation includes both the linear and the squared term of $g$, therefore it is a quadratic function.

We estimate this equation through a DOLS technique which deals with endogeneity and autocorrelation issues. The graphical solution of the optimal amount of government spending is the peak of the quadratic curve. However, the mechanism specified below can be used to calculate the optimal level of government spending using partial differentiation.

$$
\begin{aligned}
& G G I_{t}-G G I_{t-1}=\alpha_{0}+\gamma_{1} g_{t}-\gamma_{2} g_{t}^{2}+\phi X_{t}^{2} \\
& \frac{\partial\left(G G I_{t}-G G I_{t-1}\right)}{\partial\left(g_{t}\right)}=\gamma_{1}-2\left(\gamma_{2}\right) g_{t} \\
& 0=\gamma_{1}-2\left(\gamma_{2}\right) g_{t} \\
& g_{t}^{*}=\frac{\gamma_{1}}{2 \gamma_{2}}
\end{aligned}
$$

As the results shows a negative relationship between public spending on housing and green economic growth, and a positive relationship between public spending on economic affairs and public spending on health and green economic growth, we attempts in this part to check the existence of linear or nonlinear relationship between these variables and green economic growth.

The results in Table 9 show a nonlinear relationship between public spending on housing and green economic growth. In Table 11, the results show a nonlinear relationship between public spending on health and green economic growth. In Table 10, the results show a linear relationship between public spending on economic affairs and green growth. 
Table 9: DOLS Housing

\section{Dependent variable: GGIQ}

\begin{tabular}{|c|c|c|}
\hline Variables & Coefficient & Prob. \\
\hline LAG1 & 1.392 & $0.000 * * *$ \\
\hline DEFENQ & 0.865 & 0.561 \\
\hline HOUSINGQ & -0.356 & $0.077 *$ \\
\hline HOUSINGQSQ & 0.017 & $0.095^{*}$ \\
\hline AFFAIRSQ & 0.051 & 0.546 \\
\hline GENERALQ & -0.163 & 0.482 \\
\hline ENVIRONQ & -0.864 & 0.576 \\
\hline INFQ & 0.009 & $0.000 * * *$ \\
\hline ORDERQ & 0.735 & 0.778 \\
\hline RECREATIONQ & -2.333 & 0.623 \\
\hline SOCIALQ & -0.144 & 0.444 \\
\hline HEALTHQ & 0.510 & 0.144 \\
\hline TRADEQ & 0.038 & $0.000 * * *$ \\
\hline CRISISQ & -0.082 & 0.729 \\
\hline BREAKQ & -4.245 & $0.000 * * *$ \\
\hline R-squared & 0.999 & \\
\hline Adjusted R-squared & 0.999 & \\
\hline
\end{tabular}


Table 10: DOLS Affairs

\section{Dependent variable: GGIQ}

\begin{tabular}{|c|c|c|}
\hline Variables & Coefficient & Prob. \\
\hline LAG1 & 0.809 & $0.000 * * *$ \\
\hline DEFENSEQ & -1.972 & $0.082 *$ \\
\hline HOUSINGQ & -0.333 & 0.300 \\
\hline AFFAIRSQ & 0.101 & $0.082^{*}$ \\
\hline AFFAIRSQSQ & 0.001 & $0.096^{*}$ \\
\hline GENERALQ & 0.066 & 0.710 \\
\hline ENVIRONQ & -1.169 & 0.346 \\
\hline INFQ & -0.001 & 0.707 \\
\hline ORDERQ & 0.824 & 0.503 \\
\hline RECREATIONQ & 3.156 & 0.355 \\
\hline SOCIALQ & 0.087 & 0.528 \\
\hline HEALTHQ & -0.031 & 0.894 \\
\hline TRADEQ & -0.014 & $0.073^{*}$ \\
\hline CRISISQ & 0.053 & 0.823 \\
\hline BREAKQ & -0.756 & $0.006 * * *$ \\
\hline R-squared & 0.980 & \\
\hline Adjusted R-squared & 0.977 & \\
\hline
\end{tabular}


Table 11: DOLS health

\section{Dependent variable: GGIQ}

\begin{tabular}{|c|c|c|}
\hline Variables & Coefficient & Prob. \\
\hline LAG1 & 1.294 & $0.000 * * *$ \\
\hline DEFENSEQ & -0.104 & 0.919 \\
\hline HOUSINGQ & -0.185 & 0.283 \\
\hline AFFAIRSQ & 0.089 & 0.052 \\
\hline GENERALQ & -0.099 & 0.431 \\
\hline ENVIRONQ & -0.006 & 0.996 \\
\hline INFQ & 0.006 & $0.008^{* * *}$ \\
\hline ORDERQ & -0.052 & 0.979 \\
\hline RECREATIONQ & 1.844 & 0.556 \\
\hline SOCIALQ & -0.073 & 0.431 \\
\hline $\begin{array}{l}\text { HEALTHQ } \\
\end{array}$ & 0.916 & $0.062^{*}$ \\
\hline HEALTHQSQ & -0.337 & $0.047 * *$ \\
\hline TRADEQ & 0.028 & 0.011 \\
\hline CRISISQ & -0.069 & 0.660 \\
\hline BREAKQ & -4.003 & $0.000^{* * * *}$ \\
\hline R-squared & 0.999 & \\
\hline Adjusted R-squared & 0.999 & \\
\hline
\end{tabular}

$*, * *, * * *$ denote the statistical significance at $10 \%, 5 \%, 1 \%$ level

Based on equation (10), the maximal amount of public spending is as following (Table 12):

\section{Table 12: Maximum spending}

\begin{tabular}{|l|l|}
\hline Variables & Maxima \\
\hline Housing & 10.181 \\
\hline Health & 1.358 \\
\hline
\end{tabular}

The results in Table 12 suggest that the curve peaks where public spending on housing is approximately equal to $10.18 \%$ of total government expenditure. In the case of public expenditure on health, the curve peaks when this specific spending is approximately equal to $1.36 \%$ of total government expenditure. 


\section{Discussion}

The DOLS and FMOLS analysis results show a positive effect of previous green economic growth, public spending on economic affairs, and public spending on health on green economic growth. The results also show a positive effect of inflation rate and trade openness on green economic growth. However, there is a negative relationship between public spending on housing.

In addition, there is a linear relationship between public spending on economic affairs and green growth; and, a nonlinear relationship between public spending on housing and green economic growth, and between public spending on health and green economic growth. This nonlinear relationship suggests that the amount of public spending can/cannot exceed a certain level; otherwise this spending will contribute/reduce green economic growth. In our study case, public spending on housing have to exceed $10.18 \%$ of total government expenditure to contribute to green growth, while public expenditure on health, cannot exceed $1.36 \%$ of total government expenditure. Lastly, the results show that the 2015 breakpoint has a negative and significant effect on economic growth, while the 2008 financial crisis effect is not significant.

As public spending on economic affairs considers spending in agriculture, forestry, fishing, hunting, fuel, energy, mining, manufacturing and construction, transport, communication, industries, its positive relationship with green economic growth may be due to the increasing of regulation in the environment protection such as the development of environmental-friendly energy (Solar PV; Wind; Bioenergy), the reduction of the need of fossil fuel energy. It may also be due to the creation of green jobs, such as those in afforestation, reforestation, and forest management. So, this spending might reduce poverty, hence contributing to green growth. The development of environmentalfriendly transportation networks such as high-rail trains, environmental-friendly cars (hybrid), and bus, may also contribute to growth. In addition, the management of fishing industry through individual transferable quota (ITQ) system may permit to protect ocean fisheries from overexploitation, enhance food security, and hence contribute to green growth. To end, the transforming and upgrading of traditional manufacturing industries through technological innovation, the improvement of energy efficiency, the assistance of industries focusing on energy saving and environmental protection may also contribute to green growth.

The negative relationship between public spending on housing and green economic growth may be due to the amount of the expenditure allocated to this specific spending. In effect, the results show that public spending on housing will contribute to growth if this spending exceeds $10.18 \%$ of total government expenditure. This spending may have a positive effect on green economic growth through the implementation of resource-efficient and disasterproof infrastructure, the implementation of policies to encourage sustainable consumption ( water-saving products, green cars, energy-efficient, and land-saving housing), the increasing of the availability of recycling facilities; the implementation of regulation on green public procurement.

The 2015Q1 breakpoint, which seems due to the deceleration of China's economic growth, has a negative impact on green growth because of, firstly, China's shifts from an investment driven growth model to one more focused on consumer demand. Secondly, the decrease of global commodities' prices at the end of 2014 and the beginning of 
2015 due to the decline in commodities (oil, iron ore, copper, and cereals) demand. The positive impact of public spending on health on green growth can be explained by investment in health such as medical products, appliances and equipment (cleaner air products), and outpatient services, which contribute to population well-being, hence workers' productivity. As public health polices consider reducing pollution through the dismantling of coal-fired plants, reforestation; it also contributes to better water and soil quality, hence improving agriculture and growth.

The positive relationship between trade openness and green growth can be explained by the fact that trade openness policies nowadays consider environmental risk management of investment and responsible investment principles, which ease environmental-friendly investment and projects, and green innovations. This policy also considers establishing a credit rating system for enterprises' environmental behaviors, building a green rating system in banks, and exploring mechanisms for earmarked funds for national ecological compensation. The positive effect of inflation on green growth in China may be due to the fact that inflation increases consumption, leading to spending and growth. Besides, the level of inflation in this period, which is moderate, is also a growth contributor.

\section{Conclusion}

This paper examined the link between public spending and green economic growth in China for 1993Q1-2018Q4. This study considered the linear and nonlinear relationship instead of the other studies that only pay attention to the linear relationship. Specifically, this paper pays attention to the impact of disaggregated public spending on green economic growth by using DOLS, and FMOLS approaches. The results indicate a positive effect of public spending on economic affairs and public spending on health on green economic growth. The results also show a positive impact of inflation and trade openness on green economic growth; while a negative effect of public spending on housing, on green growth and a negative relationship between the 2015Q1 breakpoint and green economic growth. The results of this paper have three important policy implications. First, since the results indicate a positive effect of public spending on economic affairs and public spending on health on green growth, the Chinese government must implement policies to increase these spendings while paying attention to the level of the expenditure on health (which can impacts negatively on green growth by $1.36 \%$ of total government expenditure). Second, policymakers have to pay attention to the spending allocated to housing because, under a certain level $(10.18 \%$ of total government expenditure), this spending negatively impacts green growth. Third, China policymakers have to encourage trade openness and manage inflation to contribute to green growth. To end, this analysis can be extended by addressing the role of taxation in the study of the link between public spending and green growth. Specifically, it would be to examine the effect of aggregated and/or disaggregated taxes in this relationship. Another important question would be to examine the directions and magnitude of the causality between these different variables. 


\section{References}

Armey, R.K. (1995) The Freedom Revolution. Regnery Publishing.

Danish, Zhang, J., Hassan, S. T., \& Iqbal, K. (2019). Toward achieving environmental sustainability target in organization for economic cooperation and development countries: The role of real income, research and development, and transport infrastructure. Sustainable Development, 1-10. https://doi.org/10.1002/sd.1973

Dogan, E. and Seker, F (2016), Determinants of CO2 emissions in the European Union: The role of renewable and non-renewable energy, Renewable Energy, 94, (C), 429-439

Elliott G., Rothenberg T. J., and Stock J. (1996), Efficient Tests for an Autoregressive Unit Root, Econometrica, 64, (4), 813-36

Ertuğrul H. M., P.F. Gebeşoğlu P. F., Atasoy B.S. (2018), Mind the gap: Turkish case study of policy change in private pension schemes Borsa Istanbul Review, 18-2, pp. 140-149

Feridun M. (2009). "Determinants of Exchange Market Pressure in Turkey: An Econometric Investigation," Emerging Markets Finance and Trade, Taylor \& Francis Journals, vol. 45(2), pages 65-81, March.

Glynn, J.; Perera, N.; Verma, R. (2007). Unit root tests and structural breaks: A survey with applications, Journal of Quantitative Methods for Economics and Business Administration 3(1): 63-79.

IMF, (2019), International Monetary Fund Government Finance Statistics 2019, IMF. Washington, D.C.

Kao, C. and Chiang, M-H (1999), On the Estimation and Inference of a Cointegrated Regression in Panel Data, No 2, Center for Policy Research Working Papers, Center for Policy Research, Maxwell School, Syracuse University

Kao, C. and Chiang, M.-H. (2001), "On the estimation and inference of a cointegrated regression in panel data", Baltagi, B.H., Fomby, T.B. and Carter Hill, R. (Ed.) Nonstationary Panels, Panel Cointegration, and Dynamic Panels (Advances in Econometrics, Vol. 15), Emerald Group Publishing Limited, Bingley, pp. 179-222. https://doi.org/10.1016/S0731-9053 (00)15007-8

Keho, Y. (2012). The Basics of Linear Principal Components Analysis. 
KOICA (2012), “KOICA’s triangular co-operation implementation strategy”, (unpublished), Korea International Development Agency, Seoul.

Kuznets, S. (1955). Economic Growth and Income Inequality. The American Economic Review, 45(1), 1-28. Retrieved January 27, 2021, from http://www.jstor.org/stable/1811581

Li, J., Xu, B., (2018). Curse or blessing: how does natural resource abundance affect green economic growth in China? Econ. Res. J. 9, 151-167.

Lin, B., Zhu, J., (2019). Impact of energy saving and emission reduction policy on urban sustainable development: empirical evidence from China. Appl. Energy 239, 12-22.

Matraeva, L., Solodukha, P., Erokhin, S., Babenko, M., (2019). Improvement of Russian energy efficiency strategy within the framework of "green economy" concept (based on the analysis of experience of foreign countries). Energy Policy 125, 478-486.

Musango, J.K., Brent, A.C., Bassi, A.M., (2014). Modelling the transition towards a green economy in South Africa. Technological forecasting and social change 87, 257-273.

Narayan S., Narayan P.K. (2004) Determinants of demand of Fiji's exports: An empirical investigation. The Developing Economics, 42 (1) (2004), pp. 95-112

Pesaran M.H, Shin Y., Smith R. J., (2001). Bound Testing Approaches to the Analysis of Long Run Relationships. Journal of Applied Econometrics. Special Issue, 16 (2001), pp.289-326

Phillips P., and Hansen B., (1990), Statistical Inference in Instrumental Variables Regression with I(1) Processes, Review of Economic Studies, 57, (1), 99-125

Phillips, P. and Perron, P. (1988), “Testing for a Unit Root in Time Series Regression”, Biometrica 75(2), pp. $335-346$.

Qin, X.,Wang, X., Xu, Y.,Wei, Y., (2019). Exploring driving forces of green growth: empirical analysis on China's iron and steel industry. Sustainability $11(4), 1122$.

Reilly, J.M., (2012).Green growth and the efficient use of natural resources. Energy Econ. 34, S85-S93. 
Sarkodie SA, Adams S (2018) Renewable energy, nuclear energy, and environmental pollution: accounting for political institutional quality in South Africa. Sci Total Environ 643:1590-1601

Shah K., Dulal H. (2015) Household capacity to adapt to climate change and implications for food security in Trinidad and Tobago. Reg Environ Change. doi:10.1007/s10113-015-0830-1

Stock, J. and Watson M., (1993), A Simple Estimator of Cointegrating Vectors in Higher Order Integrated Systems, Econometrica, 61, (4), 783-820

United Nations Economic and Social Commission for Asia and the Pacific Report (2012). Bangkok, Thailand

Wang, X., Shao, Q., (2019). Non-linear effects of heterogeneous environmental regulations on green growth in G20 countries: evidence from panel threshold regression. Sci. Total Environ. 660, 1346-1354.

Wu, W., Cheng, Y., Lin, X., Yao, X., (2019). How does the implementation of the policy of electricity substitution influence green economic growth in China? Energy Policy 131, 251-261.

World Bank, (2019). Word Development Indicators Database. World Bank, Washington

Yi, H., Liu, Y., (2015). Green economy in China: regional variations and policy drivers. Glob. Environ. Chang. 31, 11-19.

Zivot, E. and Andrews, D.W.K. (1992). Further Evidence on the Great Crash, the Oil-price Shock and the Unit-root Hypothesis. Journal of Business \& Economic Statistics.10, 251270. 